\title{
COMPARISON OF SALMONELLA RECOVERY RATES BY USING PLATING AND POLYMERASE CHAIN REACTION METHODS ON SAMPLES OBTAINED FROM A ONE YEAR SURVEILLANCE SURVEILLANCE PROGRAM IN AN INTEGRATED PIG PRODUCTION SYSTEM
}

N. Korsak ${ }^{1}$, B. Jacob ${ }^{1}$, G. Etienne ${ }^{1}$, E. Flament ${ }^{2}$, G. Daube ${ }^{1}$

${ }^{1}$ Liege University, Faculty of Veterinary Medicine, Food Science Department, Sart-Tilman B43bis, B-4000 Liege, Belgium, Phone: +32-4-3664029, Fax: +32-4-3664753, E-mail: nkorsak@ulg.ac.be

${ }^{2}$ Industrial partner, B-4880 Aubel, Belgium.

\section{INTRODUCTION}

Many methods exist to recover Salmonella spp in food or non-food materials. Cultural methods comprise different phases consisting in pre-enrichment, selective enrichment, plating on selective solid media and finally, identification. One of the major drawbacks is the non-detection of viable, non-culturable bacteria, that still might be responsible for disease in the field (Candrian, 1995). The same author also notes how time-consuming are classical methods, in comparison with DNA hybridisation techniques. In last decades various direct and indirect methods have been marketed. Among these, PCR methods have several advantages, including: a sensitivity and a specificity estimated at nearly $100 \%$, high rapidity and automatisation. The aim of the present work was to compare two different Salmonella recovery methods in term of efficiency, rapidity and reliability.

\section{MATERIAL}

- 14 pig herds located in the Southern part of Belgium, were followed

- from $1^{\text {st }}$ November 1999 to $31^{\text {st }}$ October 2000

- 6,800 slaughter pigs produced each year

- one herd, belonging to the production system and composed of only 600 sows, provides all weaned piglets

\section{METHODS}

Table 1 : Sampling plan

\begin{tabular}{|c|c|c|}
\hline Sample matrix & Method of sample & Volume of sample \\
\hline Feeds & Random sampling when loading the lorry. & $25 \mathrm{~g}$ of meal \\
\hline Breeding & $\begin{array}{l}1 \mathrm{x} / \text { month } \\
\text { (every farrow should be inspected) }\end{array}$ & 5 faeces samples pooled in $25 \mathrm{~g}$ \\
\hline $\begin{array}{l}\text { Weaned pigs } \\
(\rightarrow 20 \mathrm{~kg})\end{array}$ & $\begin{array}{l}\text { Once on every batch } 8 \text { days before going } \\
\text { out }\end{array}$ & 5 faeces samples pooled in $25 \mathrm{~g}$ \\
\hline Fattening & $\begin{array}{l}\text { Twice on every batch } \\
\text { (after } 2 \text { months and } 4 \text { months of fattening) }\end{array}$ & 5 faeces samples pooled in $25 \mathrm{~g}$ \\
\hline Slaughterhouse & Once on every batch & $\begin{array}{l}5 \text { samples of contents of large } \\
\text { intestine pooled in } 25 \mathrm{~g}\end{array}$ \\
\hline Carcasses & Once on every batch & $\begin{array}{l}\text { Pool of } 5 \text { surface swabs } \\
\left(5 \times 600 \mathrm{~cm}^{2}\right)^{(1)}\end{array}$ \\
\hline Cutting room & Random sampling & $25 \mathrm{~g}$ of retail cut \\
\hline Mincing room & Random sampling & $25 \mathrm{~g}$ of ground minced meat \\
\hline Butcheries & Random sampling & $25 \mathrm{~g}$ of ground minced meat \\
\hline
\end{tabular}

(1) same pigs as those sampled for contents of large intestine. Areas of carcass swabbing were adapted from areas chosen by Korsak et al. (1998).

\section{Classical bacteriological analyses (}

A 18 hours Buffered Peptone Water (BPW) pre-enrichment step is operated at $37^{\circ} \mathrm{C}(25 \mathrm{~g}+225 \mathrm{ml} \mathrm{BPW}$. After a streak on Diassalm and incubation at $42{ }^{\circ} \mathrm{C}$ during 24 hours, isolation is achieved on XLT4 medium. Suspected colonies appear red with a dark centre disc following a 22 hour incubation at $37^{\circ} \mathrm{C}$. Confirmation is achieved with classical biochemical and serological methods.

\section{PCR protocol (Probelia'TM)}

Marketed PCR protocol was modified only for fecal matter by adding a second overnight enrichment in Rappaport-Vassiliadis broth after the BPW pre-enrichment

\section{Test values}

Since both methods were used on the same samples, it was possible to calculate a relative sensitivity and a relative specificity for different types of matrixes using Diassalm method as reference. Kappa coefficients were also calculated.

\section{RESULTS}

Table 2 : Relative sensitivity (SER) and specificity (SPR) for Salmonella recovery using PCR method at different sampling places

\begin{tabular}{|c|c|c|c|c|c|c|c|c|c|}
\hline & $\mathrm{n}$ & SER & SPR & Kappa & & $\mathrm{n}$ & SER & SPR & Kappa \\
\hline Feeds & 239 & $61.9 \%$ & $98.2 \%$ & 0.657 & $\begin{array}{l}\text { Fattening } \\
\text { pigs } 2 \mathrm{~m}\end{array}$ & 121 & $66.7 \%$ & $89.6 \%$ & 0.48 \\
\hline $\begin{array}{l}\text { Pregnant } \\
\text { sows }\end{array}$ & 60 & $37.5 \%$ & $92.3 \%$ & 0.315 & $\begin{array}{l}\text { Fattening } \\
\text { pigs } 4 \mathrm{~m}\end{array}$ & 114 & $43.8 \%$ & $93.9 \%$ & 0.408 \\
\hline $\begin{array}{l}\text { Lactating } \\
\text { sows }\end{array}$ & 149 & $20 \%$ & $93.8 \%$ & 0.093 & $\begin{array}{l}\text { Contents } \\
\text { of large } \\
\text { intestine }\end{array}$ & 110 & $36 \%$ & $96.7 \%$ & 0.344 \\
\hline $\begin{array}{l}\text { Weaned } \\
\text { pigs }\end{array}$ & 69 & $0 \%$ & $94.0 \%$ & -0.04 & Pork meat & 259 & $91.7 \%$ & $95.5 \%$ & 0.625 \\
\hline
\end{tabular}

\section{DISCUSSION \& CONCLUSION}

PCR relative sensitivity of faeces average $46 \%$, it was very low for contents of large intestine at slaughterhouse and was excellent for pork meat. This constitutes a major drawback, as it does not guarantee certitude for a negative result. Thus, to know Salmonella spp status of pigs before slaughtering, this method is not suitable to detect positive herds. In contrast, PCR relative specificity averages $90 \%$ and seemed not to be affected by faeces. For Kappa coefficients, values superior to 0.6 were only obtained for animal feed and pork meat

Probelia $^{\mathrm{TM}}$ method appeared only reliable for pork meat and animal feeds.

\section{REFERENCES}

Candrian, U., 1995. Polymerase chain reaction in food microbiology. J. Microbiol. Meth. 23,89-103.

Korsak, N., Daube, G., Ghafir, Y., Chahed, A., Jolly, S., and Vindevogel, H., 1998. An efficient sampling technique used to detect

four foodborne pathogens on pork and beef carcasses in nine Belgian abattoirs. J. Food Prot. 61,535-541. 